\title{
Nitrogen dynamics of the surfgrass Phyllospadix iwatensis
}

\author{
N. Hasegawa ${ }^{1,4, *}$, H. Iizumi ${ }^{2}$, H. Mukai ${ }^{3}$ \\ ${ }^{1}$ Graduate School of Science, Hokkaido University, 5 Aikappu, Akkeshi-cho Akkeshi-gun, Hokkaido 088-1113, Japan \\ ${ }^{2}$ Japan Sea National Fisheries Research Institute, 1-5939-22 Suidou-cho, Niigata 951-8121, Japan \\ ${ }^{3}$ Field Science Center for Northern Biosphere, Hokkaido University, 5 Aikappu, Akkeshi-cho Akkeshi-gun, \\ Hokkaido 088-1113, Japan \\ ${ }^{4}$ Present address: Akkeshi Marine Station, Hokkaido University, 5 Aikappu, Akkeshi-cho Akkeshi-gun, \\ Hokkaido 088-1113, Japan
}

\begin{abstract}
Nitrogen uptake by leaves and roots of the surfgrass Phyllospadix iwatensis Makino, growing on the subtidal rocky shore of Akkeshi Bay, Japan, was assessed by experimental measurements for dissolved inorganic nitrogen (DIN) uptake and field measurements for plant biomass and DIN concentrations in both the water column and sediments. Mainly, leaves of P. iwatensis contributed to total nitrogen uptake in fall and winter when DIN concentration in the water column was high. Otherwise, contributions of roots were higher than those of leaves in spring and summer when DIN in the water column was low. Both leaves and roots contributed to the nitrogen acquisition. However, the nitrogen uptake from external media would not be enough for nitrogen incorporation in the highly productive season. Internally recycled nitrogen may play an important role in this season.
\end{abstract}

KEY WORDS: Seagrass $\cdot$ Phyllospadix iwatensis $\cdot$ Nitrogen uptake $\cdot$ Retention

Resale or republication not permitted without written consent of the publisher

\section{INTRODUCTION}

Seagrasses achieve high production and play important roles in the material dynamics of the coastal ecosystems. The high productivity requires high nutrient incorporation, and limited productivity due to shortages of nutrients has been reported in many seagrass populations (Short 1987, Duarte 1990, Bulthuis et al. 1992, Kenworthy \& Fouseca 1992, Alcoverro et al. 1997, Udy \& Dennison 1997, Lee \& Dunton 1999). Seagrasses can use both internal and ambient nitrogen sources. The use of an internal nitrogen source requires the nitrogen translocation from old or storage organs to young growing organs through the developed vascular system. Nitrogen translocation plays an important role in nitrogen economics of terrestrial angiosperm; however, it has been suggested not to be strongly developed in seagrasses (Hemminga et al. 1999). In contrast to terrestrial vascular plants, aquatic vascular plants including seagrasses take up dissolved inorganic nitrogen (DIN) not only from sediment pore- water, but also from the water column, through belowand aboveground routes, respectively (Iizumi \& Hattori 1982, Thursby \& Harlin 1982, Short \& McRoy 1984, Stapel et al. 1996, Lee \& Dunton 1999). DIN uptake rate has been suggested to depend on ambient DIN concentration, and the Michaelis-Menten model has been commonly used to describe DIN uptake kinetics in seagrasses (Thursby \& Harlin 1984, Stapel et al. 1996, Pedersen et al. 1997, Terrados \& Williams 1997). Nitrogen uptake kinetics are highly variable among species, habitats and organs (Touchette \& Burkholder 2000). Due to high ammonium $\left(\mathrm{NH}_{4}{ }^{+}\right)$concentration in sediment porewater, nitrogen uptake through roots was considered the main pathway of acquiring nitrogen from ambient sources (Short \& McRoy 1984, Thursby \& Harlin 1984). Nevertheless, it has been suggested that the nitrogen uptake rate through aboveground parts is higher than through belowground parts, and a considerable contribution of aboveground parts to the total nitrogen uptake has been indicated (Touchette \& Burkholder 2000). The aboveground 
nitrogen uptake ratio has been reported to contribute 40 to $96 \%$ of total nitrogen acquisition in Zostera marina L. (Iizumi \& Hattori 1982, Pedersen \& Borum 1992, Hemminga et al. 1994) and 52\% in Thalassia testudinum Banks ex König (Lee \& Dunton 1999). Particularly, in the case of the surfgrass Phyllospadix torreyi Watson, which grows on rocks, belowground nitrogen uptake has not been detected (Terrados \& Williams 1997). However, another rocky seagrass, Amphibolis antarctica (Labill.) Sender et Aschers ex Aschers, can uptake nitrogen from sediment porewater despite the low uptake kinetics of the belowground parts (Pedersen et al. 1997).

Phyllospadix iwatensis Makino is a surfgrass which is distributed on intertidal and subtidal rocky shores in the North West Pacific (Yabe et al. 1996). P. iwatensis grows in dense colonies and forms a thick belowground anaerobic mat with sediments and detritus (Yabe et al. 1996). Generally, in the anaerobic sediment mat, there is abundant $\mathrm{NH}_{4}{ }^{+}$that is a useful nitrogen source for seagrasses. $P$. iwatensis allocates much biomass into belowground parts (Yabe et al. 1995). The belowground parts of $P$. iwatensis are likely to be useful for attachment and nutrient storage as in $P$. torreyi. Moreover, $\mathrm{NH}_{4}{ }^{+}$uptake by belowground parts may play an important role in nitrogen acquisition in $P$. iwatensis.

This study aims to assess the contribution of nitrogen uptake of each part of Phyllospadix iwatensis from ambient nitrogen sources, and the translocation of internal nitrogen in $P$. iwatensis. To address these aims, we estimated the seasonal changes of nitrogen uptake and nitrogen requirement (the nitrogen required for growth) of each part of $P$. iwatensis through field and laboratory measurements and experiments.

\section{MATERIALS AND METHODS}

Field site and nitrogen environments. Field studies were conducted in a surfgrass bed on the rocky shore of Aikap Cape, Akkeshi Bay, Hokkaido, northern Japan, facing the Pacific Ocean $\left(43^{\circ} 00^{\prime} \mathrm{N}, 144^{\circ} 50^{\prime} \mathrm{E}\right.$, Fig. 1). This site is exposed to high waves. Phyllospadix iwatensis formed dense beds in both intertidal and subtidal zones, but this study was only conducted on the population in the highest subtidal zone.

All field research was conducted from November 2000 to October 2002. Water temperature in the study site was taken from the report of Akkeshi Marine Station (AMS), Hokkaido University from 500 m north of the study site (Nakamura et al. 2001, 2003). All sampling was done at low tide of spring tide. Measurements of DIN concentration in the water column and $\mathrm{NH}_{4}{ }^{+}$

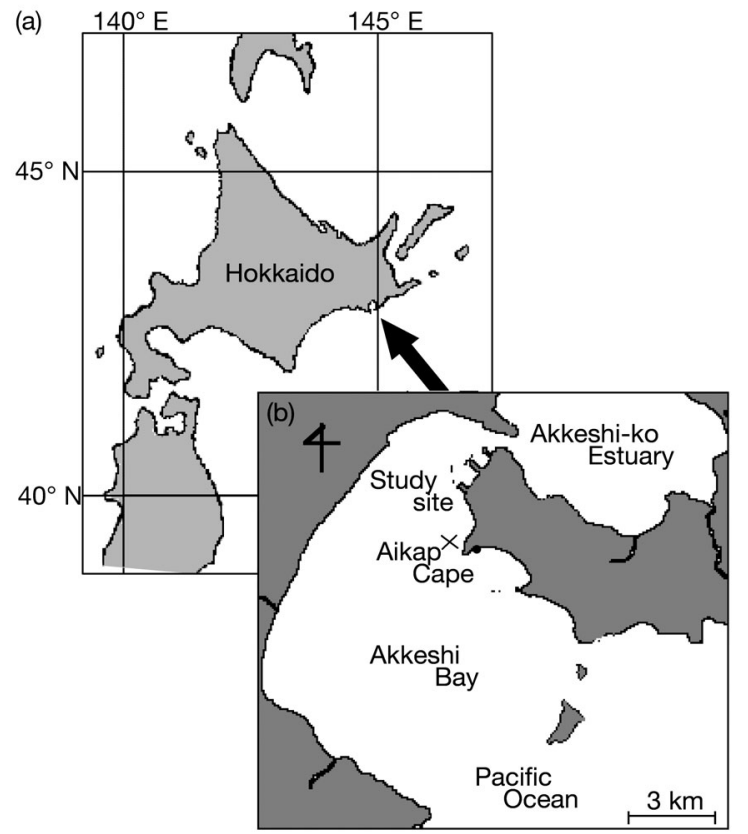

Fig. 1. (a) Map of Hokkaido, Japan. (b) Map of the study region

concentrations in sediment porewater were performed monthly and bimonthly, respectively. Five samples were collected from the surface water at each sampling and stored in ice. Within $2 \mathrm{~h}$ of collection, these samples were filtered through glass filters (Whatman GF/C). Sediment was collected with a $10 \mathrm{ml}$ syringe to a depth of $3 \mathrm{~cm}$. Three sediment samples were mixed into 1 centrifugation bottle as a single sample and the porewater was extracted by centrifugation $(3000 \times g$ for $15 \mathrm{~min}$ ) based on the methods of Dennison et al. (1987). Five samples of the porewater were collected. Ammonium concentration was determined by using the phenol hypochlorite method, immediately within 4 $\mathrm{h}$ of collection (Strickland \& Parsons 1968). Nitrate + nitrite concentrations of water sample were determined with an autoanalyzer (BRAN+LUEBBE, TRAACS800, Cd-Cu method).

Biomass. Plant biomass was measured from 5 samples almost bimonthly with a $10 \times 10 \mathrm{~cm}$ quadrat, including sediment-belowground mat complex. After cleaning, shoot number was counted and the plants were separated into aboveground parts (leaf blade and leaf sheath) and belowground parts (root and rhizome). Ash free dry weight (AFDW) was estimated from the difference between dry weight (desiccation at $80^{\circ} \mathrm{C}$ for $48 \mathrm{~h}$ ) and ash weight (combustion at $500^{\circ} \mathrm{C}$ for $4 \mathrm{~h}$ ).

Uptake experiments. Ammonium $\left(\mathrm{NH}_{4}{ }^{+}\right)$and nitrate + nitrite $\left(\mathrm{NO}_{3}{ }^{-}+\mathrm{NO}_{2}{ }^{-}\right)$uptake by aboveground parts of Phyllospadix iwatensis and $\mathrm{NH}_{4}{ }^{+}$uptake by belowground parts were measured by the incubation experiments. Although in terrestrial plants $\mathrm{NO}_{3}{ }^{-}+\mathrm{NO}_{2}{ }^{-}$ 
uptake by belowground parts is the primary inorganic nitrogen source, belowground parts of seagrasses mainly take up $\mathrm{NH}_{4}{ }^{+}$, because of high $\mathrm{NH}_{4}{ }^{+}$concentration and low $\mathrm{NO}_{3}{ }^{-}+\mathrm{NO}_{2}{ }^{-}$concentrations in porewater of anaerobic sediment (Touchette \& Burkholder 2000). In this study, $\mathrm{NO}_{3}^{-}+\mathrm{NO}_{2}^{-}$uptake by belowground parts was not measured, because of the low ratio of $\mathrm{NO}_{3}{ }^{-}+\mathrm{NO}_{2}{ }^{-}$to total DIN concentration in the porewater of this study site (5.9 to $13.5 \%$ ).

An incubation chamber for aboveground nitrogen uptake experiments was constructed from $50.0 \mathrm{~cm}$ long, $3.6 \mathrm{~cm}$ diameter cylindrical plexiglass (Fig. 2a). During the incubation, both ends of the cylinder were capped with silicone stoppers. Belowground parts of Phyllospadix iwatensis shoot were fixed in $8 \mathrm{ml}$ plastic tubes filled with filtered seawater (Whatman GF/C) by a stopper, and a magnetic stir bar was fixed to another stopper for stirring the water in the plexiglass chamber.

A $100 \mathrm{ml}$ glass flask was used for the belowground uptake experiments (Fig. 2b). To fix the belowground parts in the flask, plants were put through the silicone stopper. The gap between the plant and the hole was filled up with silicone grease.

Plants used in the experiments were collected from the field site about $1 \mathrm{wk}$ before the experiment. The rhizome of each shoot was cut to $3 \mathrm{~cm}$, and incuba-

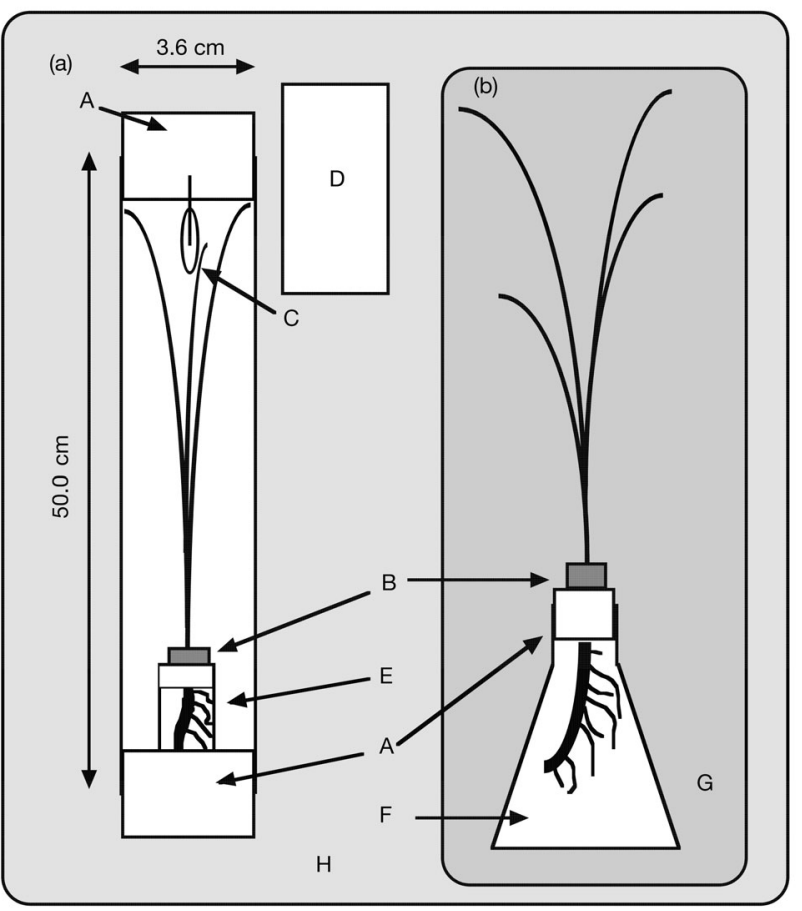

Fig. 2. Uptake experiment chambers. (a) Chamber for DIN uptake experiments by the aboveground part of Phyllospadix iwatensis. (b) Chamber for $\mathrm{NH}_{4}{ }^{+}$uptake experiments by the belowground part of $P$. iwatensis. A: silicone stopper; B: silicone grease; $\mathrm{C}$ : magnetic stirring bar; $\mathrm{D}$ : magnetic stirrer;

E: $8 \mathrm{ml}$ tube; F: $100 \mathrm{ml}$ flask; G: aquarium; H: water bath ted with the sediments in the outdoor tank $(1.5 \mathrm{~m}$ long, $1.0 \mathrm{~m}$ wide, $0.5 \mathrm{~m}$ deep), with running seawater $\left(0.6 \mathrm{t} \mathrm{h}^{-1}\right)$ in front of the AMS. A day before the experiments, these plants were moved to the $20 \mathrm{l}$ aquarium filled with filtered seawater, which was aerated and controlled at the same water temperature as the experiment. At this time, the shoots for aboveground experiments were cut to $50 \mathrm{~cm}$ and gently cleaned of epiphytes using a wet paper towel.

Uptake experiments were performed in a water bath, in which water temperature was controlled. The chamber for aboveground experiments was placed horizontally in the bath, and the chamber for belowground experiments was placed in a $20 \mathrm{l}$ aquarium filled with filtered seawater sunk in the water bath. From $2 \mathrm{~h}$ before and during the experiments, the shoots' light exposure was controlled at about $100 \mu \mathrm{mol}$ photons $\mathrm{m}^{-2} \mathrm{~s}^{-1}$ by a cool fluorescent light. The chamber for the belowground experiments was covered by an aluminium film.

The uptake rate of DIN was assumed to be represented by a decreasing rate in nutrient concentration in the chamber from the beginning $(0 \mathrm{~h})$ to the end of the incubation ( 2 or $4 \mathrm{~h}$ ). After the experiments, plants were separated into aboveground and belowground parts, and the AFDW weighed. The uptake rate was standardized by biomass ( $\mathrm{g}$ AFDW) and time (h).

Since N uptake kinetics show seasonal variation (in Thalassia testudinum; Lee \& Dunton 1999), uptake experiments were performed in 5 different seasons: February $\left(0^{\circ} \mathrm{C}\right)$, March $\left(3^{\circ} \mathrm{C}\right)$, May $\left(8^{\circ} \mathrm{C}\right)$, August $\left(18^{\circ} \mathrm{C}\right)$ and October $\left(13^{\circ} \mathrm{C}\right) 2001$. The experiments were also conducted with 5 or 6 different grades of DIN concentrations. DIN concentrations were adjusted by adding small amounts of concentrated $\mathrm{NH}_{4} \mathrm{Cl}$ or $\mathrm{KNO}_{3}$ solution. $\mathrm{NH}_{4}{ }^{+}$and $\mathrm{NO}_{3}{ }^{-}+\mathrm{NO}_{2}{ }^{-}$uptakes by aboveground parts were measured at initial $\mathrm{NH}_{4}{ }^{+}$and $\mathrm{NO}_{3}{ }^{-}+\mathrm{NO}_{2}{ }^{-}$ concentrations of 2, 5, 10, 20 and $40 \mu \mathrm{M}$. $\mathrm{NH}_{4}{ }^{+}$uptake by belowground parts was measured at initial $\mathrm{NH}_{4}{ }^{+}$ concentrations of 20,50,80,100, 150 and $200 \mu \mathrm{M}$.

Uptake rates were also plotted against the respective nutrient concentration and fitted to the MichaelisMenten model $V=V_{\max } \times S /\left(S+K_{\mathrm{m}}\right)$, where $V$ is uptake rate, $S$ nutrient concentration, $V_{\max }$ maximum uptake rate, and $K_{\mathrm{m}}$ the half saturation constant using non-linear least square regression (Stapel et al. 1996, Pedersen et al. 1997). This model is commonly used to describe nutrient uptake kinetics of aquatic plants. Hanes-Woolf plots of uptake rates were illustrated to examine the application of the Michaelis-Menten model (Lee \& Dunton 1999).

Estimation of nitrogen acquisition. Daily nitrogen acquisition ( $\mu \mathrm{g} N$ shoot $^{-1} \mathrm{~d}^{-1}$ ) by above- and belowground parts of the surfgrass was estimated from nitrogen uptake rate and above- or belowground biomass 


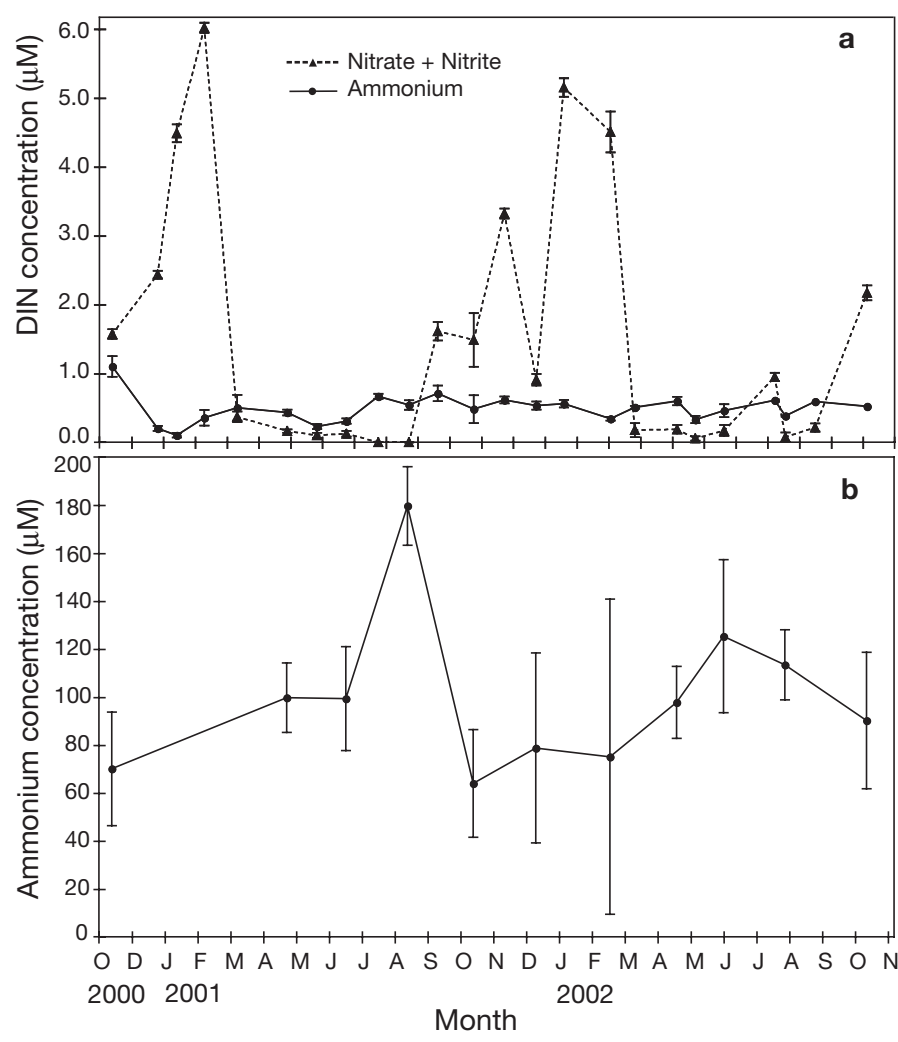

Fig. 3. (a) Water column $\mathrm{NH}_{4}{ }^{+}$and $\mathrm{NO}_{3}{ }^{-}+\mathrm{NO}_{2}{ }^{-}$concentrations, and (b) porewater $\mathrm{NH}_{4}{ }^{+}$at Aikap Cape. Vertical bars represent $\pm 1 \mathrm{SD}(\mathrm{n}=4$ or 5$)$

(Lee \& Dunton 1999). Parameters in uptake kinetics for each season were applied to the calculations of monthly nitrogen uptake rates at ambient DIN concentration. In particular, porewater $\mathrm{NH}_{4}{ }^{+}$concentration in February 2002 was applied to the estimation of the belowground nitrogen acquisition in January 2001. The contribution of nitrogen uptake by each part of the surfgrass to total nitrogen acquisition was regressed on DIN concentration. The significance of regressions was tested after the contribution data was arcsine-transformed.

Estimating nitrogen requirement. Aboveground production ( $\mu \mathrm{g}$ DW shoot ${ }^{-1} \mathrm{~d}^{-1}$ ) and nitrogen requirement ( $\mu \mathrm{g} \mathrm{N}$ shoot $^{-1} \mathrm{~d}^{-1}$ ) were estimated respectively from multiplying the leaf growth rate of shoots $\left(\mathrm{cm}^{2}\right.$ shoot $^{-1}$ $\mathrm{d}^{-1}$ ) by specific leaf weight ( $\mathrm{gWW} \mathrm{cm}^{-2}$ ), and aboveground production by nitrogen content in the youngest leaf (\% DW). Leaf growth rate of a shoot was measured from the leaf length changes during the incubation experiments (18 to $25 \mathrm{~d}, 20$ to 30 shoots) in the outdoor aquarium. The experiments were carried out 7 times between March 2001 and February 2002. Surfgrasses with sediments collected from the study site were used for the experiments. Specific weight and nitrogen content in the leaf were measured for the surfgrasses collected monthly from January 2001 to December 2001. Specific leaf weight was determined by dividing the dry weight by the total leaf area of a shoot $(n=15)$. Nitrogen content was measured using a CHN analyzer (Yanaco, MT-5) after drying at $80^{\circ} \mathrm{C}$ for $48 \mathrm{~h}(\mathrm{n}=5)$. Specific leaf weight and nitrogen content in each month were applied to the monthly calculation.

Belowground production ( $\mu$ g DW shoot ${ }^{-1} \mathrm{~d}^{-1}$ ) and nitrogen requirement ( $\mu \mathrm{g} N$ shoot $^{-1} \mathrm{~d}^{-1}$ ) were estimated by the method of Pedersen \& Borum (1993) in the incubation experiment from September to October 2001. In Phyllospadix spp., a rhizome segment is produced with every new leaf production (Short \& Duarte 2001). Based on this relationship, belowground production was calculated as the product of average rhizome internode production (reciprocal number of leaf plastochrone interval, $\mathrm{d}^{-1}$ ) and weight of full-grown rhizome internodes with roots ( $\mu \mathrm{g}$ DW internode ${ }^{-1}$ ). The belowground nitrogen requirement was calculated as the production multiplied by the nitrogen content of the rhizome with roots (\% DW). Weight and nitrogen content of rhizome internode with roots were determined at the third youngest internode and the youngest rhizome internode, respectively. The ratio of shoot nitrogen requirement in above- and belowground parts to the aboveground part in this experiment was applied in estimating the shoot nitrogen requirement in other incubation experiments.

\section{RESULTS}

\section{Environmental nutrients}

Monthly averaged water temperature changed seasonally from -0.9 to $16.7^{\circ} \mathrm{C}$. The $\mathrm{NH}_{4}{ }^{+}$concentration in the water column was less than $1.1 \mu \mathrm{M}$ throughout the

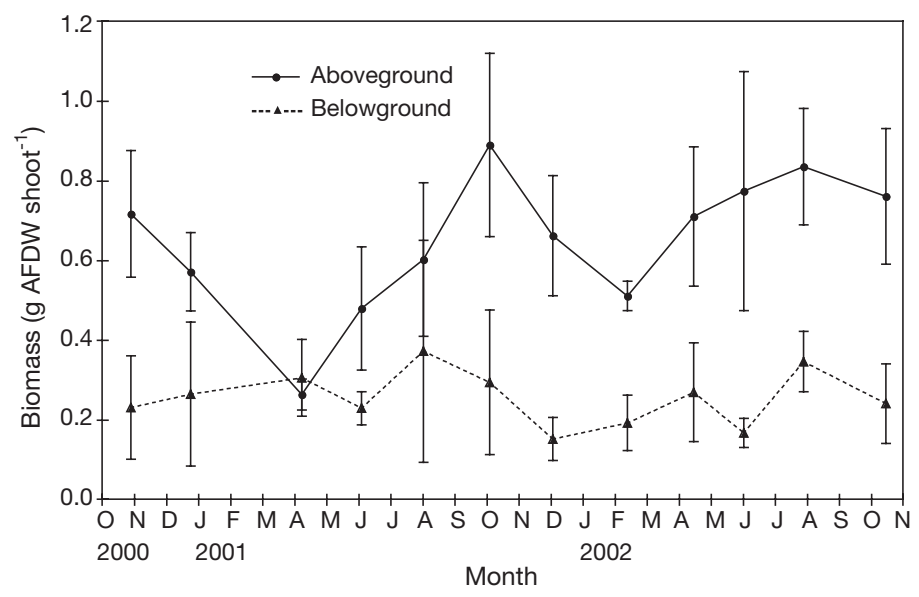

Fig. 4. Phyllospadix iwatensis. Seasonal changes in the average weight of aboveground and belowground parts. Vertical bars represent $\pm 1 \mathrm{SD}(\mathrm{n}=3$ or 5 ) 
year (Fig. 3a). The $\mathrm{NO}_{3}{ }^{-}+\mathrm{NO}_{2}{ }^{-}$concentration in the water column changed seasonally from 0 to $6.01 \mu \mathrm{M}$, increased in fall and winter, and remained lower than $0.2 \mu \mathrm{M}$ in spring and summer. The $\mathrm{NH}_{4}{ }^{+}$concentration in sediment porewater varied within a higher range (64 to $180 \mu \mathrm{M}$ ) than in the water column (Fig. 3a,b). The $\mathrm{NH}_{4}{ }^{+}$concentration in porewater increased in summer. The $\mathrm{NO}_{3}{ }^{-}+\mathrm{NO}_{2}{ }^{-}$concentration in porewater (5.5 $\pm 3.1 \mu \mathrm{M}, \mathrm{n}=5)$ was lower than the $\mathrm{NH}_{4}{ }^{+}$concentration in porewater $(99.3 \pm 39.6 \mu \mathrm{M})$.

\section{Biomass}

Aboveground biomass varied from 0.26 to $0.89 \mathrm{~g}$ AFDW shoot ${ }^{-1}$, increasing in summer and decreasing in winter (Fig. 4). From January to April 2001, a drastic decrease occurred due to scouring by drift ice in February 2001. Otherwise, drift ice did not flow into Akkeshi Bay in winter 2002 and there was no damage to surfgrass by ice scouring. Belowground biomass ranged from 0.15 to $0.37 \mathrm{~g}$ AFDW shoot ${ }^{-1}$ and a seasonal trend was not apparent.

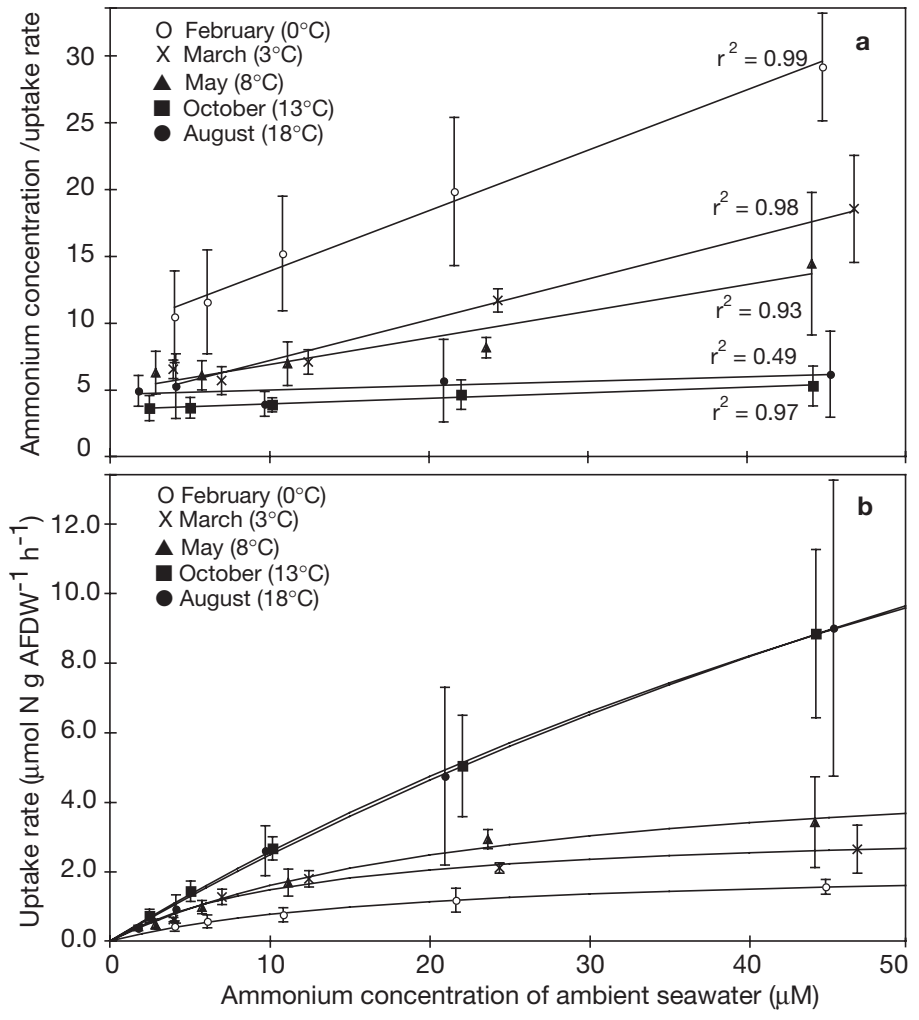

Fig. 5. Phyllospadix iwatensis. Aboveground $\mathrm{NH}_{4}{ }^{+}$uptake. (a) Hanes-Woolf plots. The regression lines were obtained from each temperature. (b) Uptake rates at different $\mathrm{NH}_{4}{ }^{+}$concentrations of ambient seawater. The curves represent the best fits of the Michaelis-Menten models obtained from each temperature. Vertical bars represent $\pm 1 \mathrm{SD}(\mathrm{n}=3$ or 4$)$

\section{Uptake experiments}

On aboveground $\mathrm{NH}_{4}{ }^{+}$and $\mathrm{NO}_{3}{ }^{-}+\mathrm{NO}_{2}{ }^{-}$uptake, the regression coefficients of the Hanes-Woolf plot were high $\left(\mathrm{r}^{2}>0.92\right)$ and significant $(\mathrm{p}<0.01)$, except for the aboveground $\mathrm{NH}_{4}{ }^{+}$uptake experiment in August $\left(18^{\circ} \mathrm{C}\right)\left(\mathrm{r}^{2}>0.49, \mathrm{p}=0.19\right)$ (Figs. 5a \& 6a). The Michaelis-Menten model was applied to the aboveground DIN uptake (Figs. 5b \& 6b). However, aboveground $\mathrm{NH}_{4}{ }^{+}$uptake rates in October $\left(13^{\circ} \mathrm{C}\right)$ and August $\left(18^{\circ} \mathrm{C}\right)$ were not saturated within the range of $\mathrm{NH}_{4}{ }^{+}$concentrations used in the experiments. The saturation rate of aboveground $\mathrm{NH}_{4}{ }^{+}$uptake increased with water temperature from 2.2 to $35.5 \mu \mathrm{mol} \mathrm{g}$ AFDW ${ }^{-1} \mathrm{~h}^{-1}$ (Table 1). The saturation $\mathrm{NO}_{3}{ }^{-}+\mathrm{NO}_{2}{ }^{-}$ uptake rate in the aboveground parts increased slightly with water temperature, and it was lower than aboveground $\mathrm{NH}_{4}{ }^{+}$uptake rate (Table 1). For belowground parts, $\mathrm{NH}_{4}{ }^{+}$uptake in February $\left(0^{\circ} \mathrm{C}\right)$ was significant as shown by linear regression of the Hanes-Woolf plot $\left(\mathrm{r}^{2}=0.90, \mathrm{p}<0.01\right)$ (Fig. 7a). The Michaelis-Menten model was, therefore, applied to the belowground $\mathrm{NH}_{4}{ }^{+}$uptake rate in February $\left(0^{\circ} \mathrm{C}\right)$ in the same way as

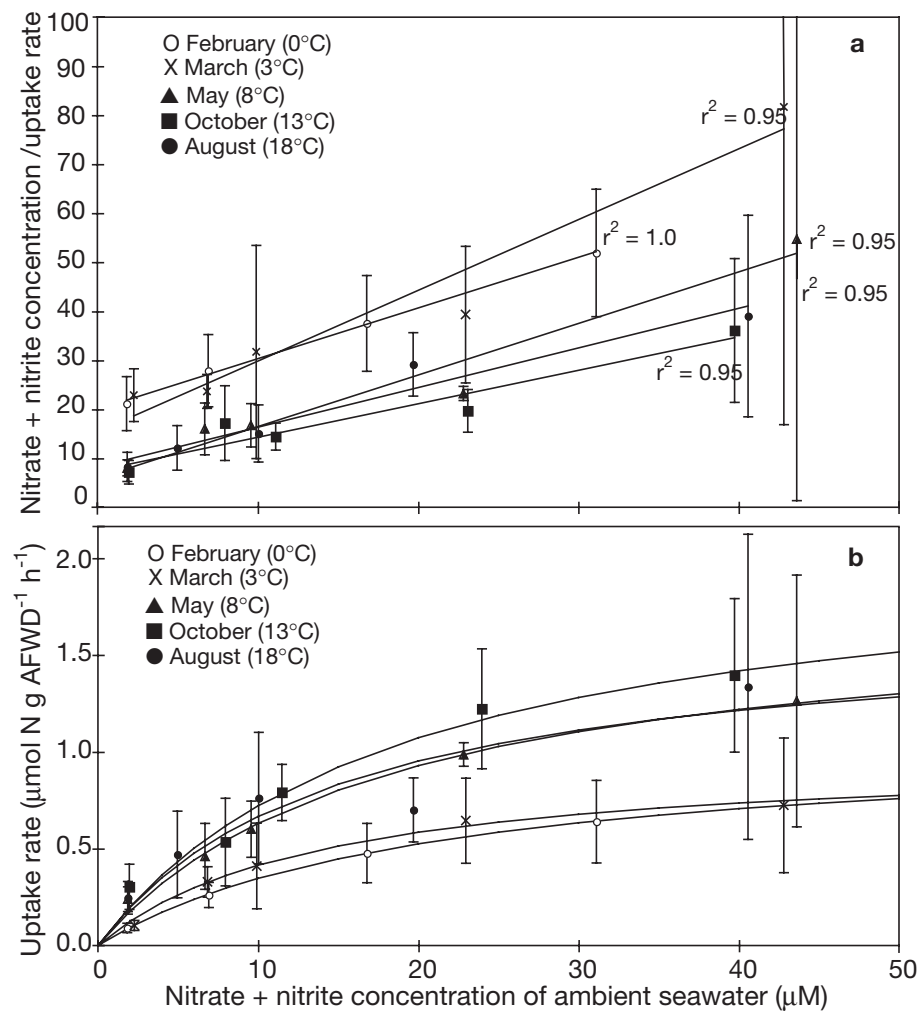

Fig. 6. Phyllospadix iwatensis. Aboveground $\mathrm{NO}_{3}{ }^{-}+\mathrm{NO}_{2}^{-}$uptake. (a) Hanes-Woolf plots. The regression lines were obtained from each temperature. (b) Uptake rates at different $\mathrm{NO}_{3}{ }^{-}+\mathrm{NO}_{2}{ }^{-}$concentrations of ambient seawater. The curves represent the best fits of the Michaelis-Menten models obtained from each temperature. Vertical bars represent $\pm 1 \mathrm{SD}(\mathrm{n}=3$ or 4$)$ 
Table 1. Phyllospadix iwatensis. Parameters of Michaelis-Menten model for nitrogen uptake. $V_{\max }$ : maximum uptake rate; $K_{\mathrm{m}}$ : half-saturation constant; $\alpha$ : uptake affinity $\left(V_{\max } / K_{\mathrm{m}}\right)$

\begin{tabular}{|lrrrrr|}
\hline & $\begin{array}{c}V_{\max } \\
(\mu \mathrm{mol} \mathrm{N} \mathrm{g} \mathrm{AFDW}\end{array}$ & $K_{\mathrm{m}}$ & $\begin{array}{c}\alpha \\
(\mu \mathrm{M})\end{array}$ & $\begin{array}{c}\mathrm{n} \\
\left(V_{\max } / K_{\mathrm{m}}\right)\end{array}$ & $\mathrm{r}^{2}$ \\
\hline Aboveground $\mathbf{N H}_{4}{ }^{+}$uptake & & & & & \\
February $\left(0^{\circ} \mathrm{C}\right)$ & 2.2 & 18.7 & 0.12 & 5 & 1.00 \\
March $\left(3^{\circ} \mathrm{C}\right)$ & 3.3 & 12.7 & 0.26 & 5 & 0.97 \\
May $\left(8^{\circ} \mathrm{C}\right)$ & 5.5 & 24.1 & 0.23 & 5 & 0.99 \\
October $\left(13^{\circ} \mathrm{C}\right)$ & 30.6 & 109.2 & 0.28 & 5 & 1.00 \\
August $\left(18^{\circ} \mathrm{C}\right)$ & 35.5 & 133.5 & 0.27 & 5 & 1.00 \\
Aboveground $\mathbf{N O}_{3}{ }^{-}+\mathbf{N O}_{2}^{-}{ }^{-}$uptake & & & & \\
February $\left(0^{\circ} \mathrm{C}\right)$ & 1.1 & 21.1 & 0.05 & 5 & 1.00 \\
March $\left(3^{\circ} \mathrm{C}\right)$ & 1.0 & 13.9 & 0.07 & 5 & 0.99 \\
May $\left(8^{\circ} \mathrm{C}\right)$ & 1.8 & 18.1 & 0.10 & 5 & 0.99 \\
October $\left(13^{\circ} \mathrm{C}\right)$ & 2.1 & 19.0 & 0.11 & 5 & 0.97 \\
August $\left(18^{\circ} \mathrm{C}\right)$ & 1.7 & 15.1 & 0.11 & 5 & 0.86 \\
Belowground $\mathbf{N H}_{4}{ }^{+}$uptake & & & & & \\
February $\left(0^{\circ} \mathrm{C}\right)$ & 0.5 & 61.3 & 0.01 & 6 & 0.82 \\
\hline
\end{tabular}

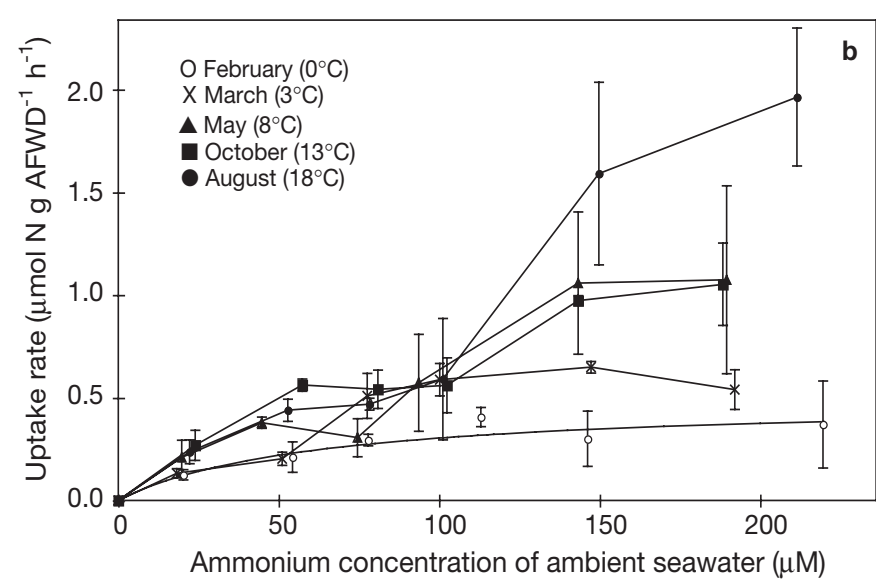

Fig. 7. Phyllospadix iwatensis. Belowground $\mathrm{NH}_{4}{ }^{+}$uptake. (a) Hanes-Woolf plots. The regression lines were obtained from each temperature. (b) Uptake rates at different $\mathrm{NH}_{4}{ }^{+}$concentrations of ambient seawater. The curves represent the best fits of the models obtained from each temperature. Vertical bars represent $\pm 1 \mathrm{SD}(\mathrm{n}=3$ or 4$)$ the aboveground DIN uptake rate (Fig. 7b, Table 1). However, the regression in March $\left(3^{\circ} \mathrm{C}\right)$, May $\left(8^{\circ} \mathrm{C}\right)$, October $\left(13^{\circ} \mathrm{C}\right)$ and August $\left(18^{\circ} \mathrm{C}\right)$ was not significant $\left(\mathrm{r}^{2}=0.50,0.15,0.63\right.$ and 0.02, respectively, p > 0.05) (Fig. 7a), and the Michaelis-Menten model was not applied to the belowground $\mathrm{NH}_{4}{ }^{+}$ uptake in these seasons. The belowground $\mathrm{NH}_{4}{ }^{+}$uptake rate in March $\left(3^{\circ} \mathrm{C}\right)$, May $\left(8^{\circ} \mathrm{C}\right)$, October $\left(13^{\circ} \mathrm{C}\right)$ and August $\left(18^{\circ} \mathrm{C}\right)$ increased with $\mathrm{NH}_{4}{ }^{+}$ concentration and saturated twice (Fig. 7b). Moreover, belowground $\mathrm{NH}_{4}{ }^{+}$ uptake kinetics increased with water temperature $\left(0\right.$ to $\left.18^{\circ} \mathrm{C}\right)$. With the exception of the uptake rate in February $\left(0^{\circ} \mathrm{C}\right)$, field belowground $\mathrm{NH}_{4}{ }^{+}$ uptake rate was estimated from the linear relationship between $\mathrm{NH}_{4}{ }^{+}$ concentration and $\mathrm{NH}_{4}{ }^{+}$uptake rate in experiments at just above and below the field $\mathrm{NH}_{4}{ }^{+}$concentration.

\section{Nitrogen acquisition}

Daily total nitrogen acquisition ranged from 57.3 to $250.2 \mu \mathrm{g} \mathrm{N}$ shoot $^{-1} \mathrm{~d}^{-1}$ and average acquisition was $108.2 \pm 57.3 \mu \mathrm{g} \mathrm{N}$ shoot $^{-1} \mathrm{~d}^{-1}$ (Fig. 8). Nitrogen acquisition from water column $\mathrm{NH}_{4}^{+}$ranged from 2.2 to $73.8 \mu \mathrm{g} \mathrm{N}$ shoot ${ }^{-1} \mathrm{~d}^{-1}$, and seasonal fluctuation was not observed. Aboveground acquisition from water column $\mathrm{NO}_{3}^{-}+\mathrm{NO}_{2}^{-}$ranged from 0 to $55.0 \mu \mathrm{g} \mathrm{N}^{-1}$ shoot $^{-1} \mathrm{~d}^{-1}$, and increased in fall and winter, but was very low in spring and summer. Belowground nitrogen acquisition from porewater $\mathrm{NH}_{4}{ }^{+}$was highly variable, ranging from 13.9 to $221.4 \mu \mathrm{g} \mathrm{N}$ shoot ${ }^{-1} \mathrm{~d}^{-1}$. The contribution of aboveground nitrogen acquisition from water column $\mathrm{NH}_{4}{ }^{+}$ranged from 3.5 to $47.4 \%$ of total nitrogen acquisition, but was not seasonal (Fig. 9). The contribution of aboveground acquisition from water column $\mathrm{NO}_{3}{ }^{-}+\mathrm{NO}_{2}^{-}$clearly shows seasonal fluctuation, being high (24.9 to $58.6 \%$ ) in fall and winter but low (0 to $5.3 \%$ ) in spring and summer. In contrast, belowground nitrogen uptake from porewater contributed greatly in spring and summer (57.2 to $88.5 \%$ ), but the contribution decreased in fall and winter (22.1 to $38.9 \%$ ). The contribution of each nitrogen acquisition was correlated with each nutrient concentration (Fig. 10). Furthermore, contribution of aboveground $\mathrm{NO}_{3}^{-}+\mathrm{NO}_{2}^{-}$uptake and belowground $\mathrm{NH}_{4}{ }^{+}$uptake decreased with increasing $\mathrm{NH}_{4}{ }^{+}$in porewater and with increasing $\mathrm{NO}_{3}{ }^{-}+\mathrm{NO}_{2}{ }^{-}$in the water column, respectively. 


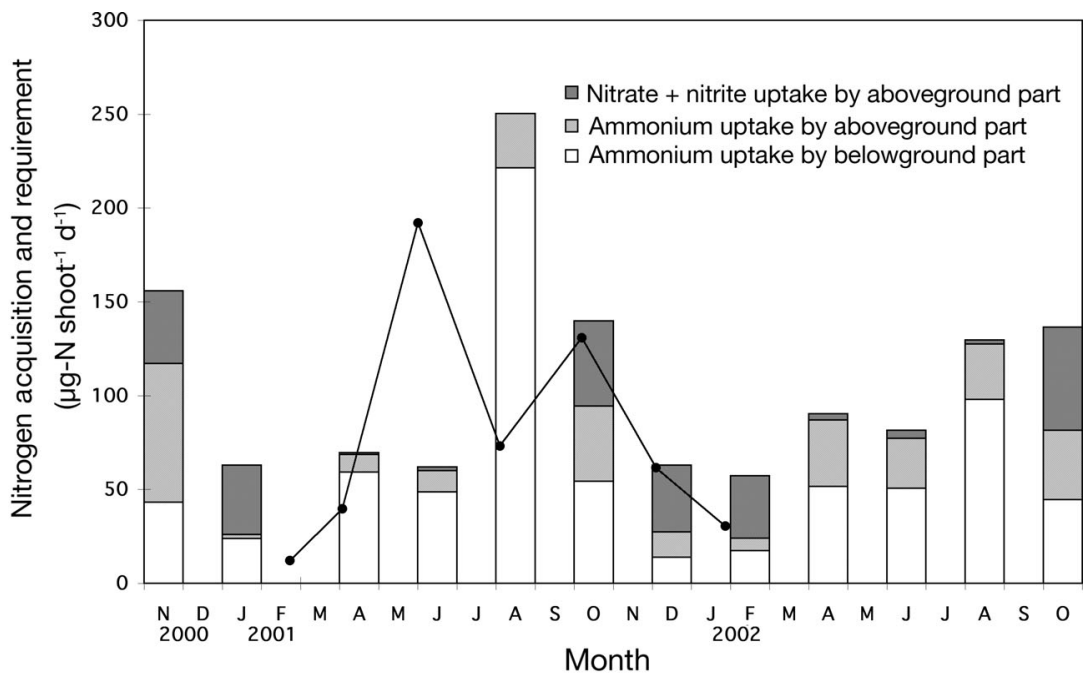

Fig. 8. Phyllospadix iwatensis. Seasonal changes in nitrogen acquisition and requirement. Bars represent nitrogen acquisition. Solid circles represent nitrogen incorporations
August (Fig. 11). Aboveground nitrogen requirement reached a maximum $\left(167 \mu \mathrm{g} \mathrm{N}\right.$ shoot $^{-1} \mathrm{~d}^{-1}$ ) between May and June, and a minimum (11 $\mu \mathrm{g} \mathrm{N}$ shoot $^{-1} \mathrm{~d}^{-1}$ ) between February and March.

Plastochrone interval and weight of the third youngest internode in the incubation experiment between September and October were $29 \mathrm{~d}$ and $32 \pm$ $25 \mu \mathrm{g}$ DW $(\mathrm{n}=22)$. The nitrogen content of the youngest internode was $1.41 \pm$ $0.14 \%$ DW $(\mathrm{n}=5)$. The belowground production and nitrogen requirement in this period were $1103 \mu \mathrm{g}$ DW shoot $^{-1} \mathrm{~d}^{-1}$ and $16 \mu \mathrm{g} \mathrm{N}$ shoot $^{-1} \mathrm{~d}^{-1}$, respectively. The ratio of the shoot nitrogen requirement to the belowground nitrogen requirement was 1.14 .

\section{Nitrogen requirement}

Leaf growth rate reached a maximum (0.97 \pm $0.20 \mathrm{~cm}^{2}$ shoot $^{-1} \mathrm{~d}^{-1}$ ) in the incubation experiment between May and June, and a minimum (0.05 \pm $0.03 \mathrm{~cm}^{2}$ shoot $^{-1} \mathrm{~d}^{-1}$ ) between February and March (Fig. 11). Specific leaf weight ranged from $638 \pm$ $73 \mu \mathrm{g} \mathrm{DW} \mathrm{cm}^{-2}$ in December to $1019 \pm 40 \mu \mathrm{g}$ DW $\mathrm{cm}^{-2}$ in June. Aboveground production showed seasonal fluctuation, ranging from $409 \mu \mathrm{g}$ DW shoot $^{-1}$ $\mathrm{d}^{-1}$ between February and March to $9919 \mu \mathrm{g}$ DW shoot $^{-1} \mathrm{~d}^{-1}$ between May and June. The nitrogen concentration in the youngest leaf was more than $2 \%$ DW during winter and spring but rapidly decreased after May and reached a minimum $(1.26 \%$ DW) in

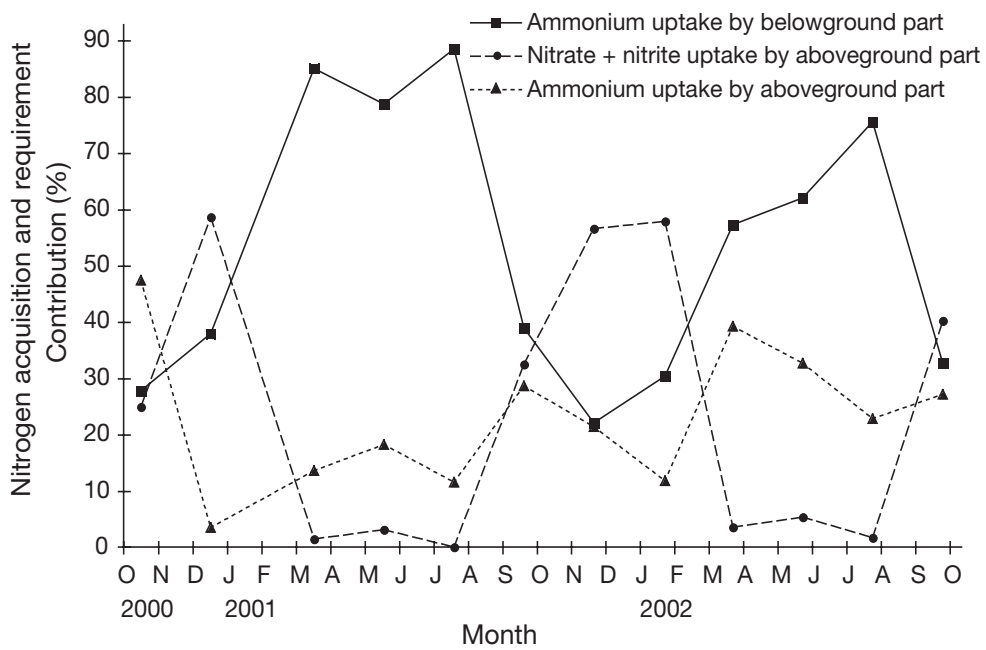

Fig. 9. Phyllospadix iwatensis. Seasonal changes in the contributions of each source of nitrogen acquisition to total nitrogen acquisition

\section{DISCUSSION}

Many seagrass species can take up nitrogen through both leaves and roots (Iizumi \& Hattori 1982, Thursby \& Harlin 1982, 1984, Short \& McRoy 1984, Stapel et al. 1996). Nevertheless, it is known that most of the nitrogen acquired by surfgrass must be channeled through the leaves, while surfgrass roots function primarily in attachment. This is due to the poor nitrogen source around the roots as well as to undetected root nitrogen uptake (Terrados \& Williams 1997). However, in some Phyllospadix iwatensis beds, plants trapped sediments and reformed their habitat to a sedimentary one, even on high-energy rocky shores (Yabe et al. 1996). The present study shows that the P. iwatensis bed in Akkeshi Bay had nitrogen-rich sediment around the roots. Furthermore, nitrogen uptake kinetics of both leaves and roots were detected.

Nitrogen uptake by Phyllospadix iwatensis varied according to season (Figs. 5 to 7). Lee \& Dunton (1999) also reported seasonal changes of nitrogen uptake kinetics in the turtlegrass Thalassia testudinum. Topinka (1978) observed temperature-dependent $\mathrm{NH}_{4}{ }^{-}$and $\mathrm{NO}_{3}{ }^{-}$uptake by brown algae. Touchette \& Burkholder (2000) revealed that glutamine synthetase activity in the eelgrass Zostera marina L. is influenced by water temperature. Water temperature is likely to be one of the important factors involved in the observed seasonal change of nitrogen uptake by $P$. iwatensis. Moreover, the direct or indirect connection between the photosynthetic and nitrogen assimilation suggests that seasonal changes in light conditions also affect nitrogen 


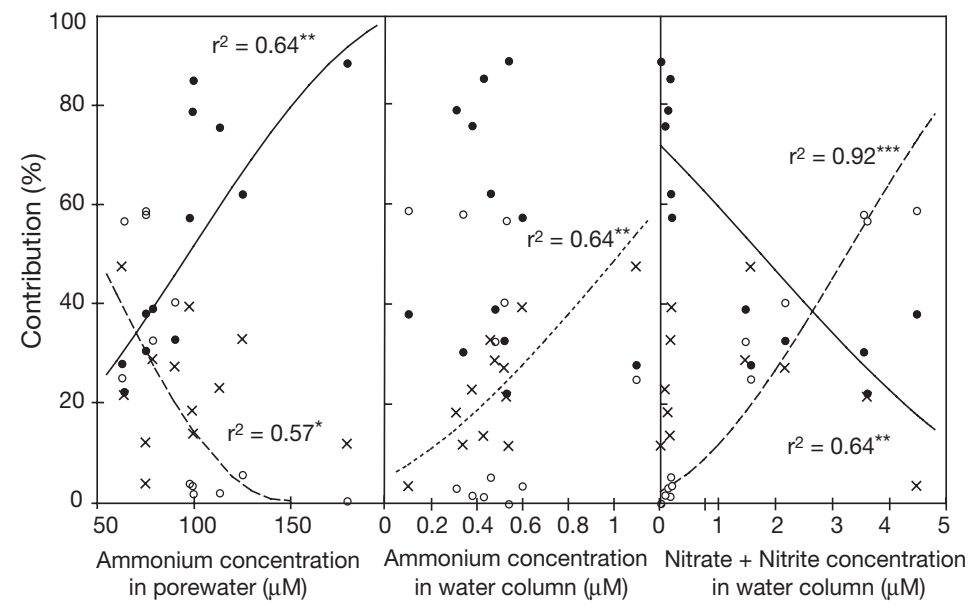

Fig. 10. Phyllospadix iwatensis. Correlation between the contribution of nitrogen uptake by each part to total nitrogen acquisition and DIN concentration. $\bullet: \mathrm{NH}_{4}{ }^{+}$uptake by belowground part; ○: $\mathrm{NH}_{4}{ }^{+}$uptake by aboveground part $x: \mathrm{NO}_{3}{ }^{-}+\mathrm{NO}_{2}{ }^{-}$uptake by the aboveground part. Solid lines: significant regressions on $\mathrm{NH}_{4}{ }^{+}$uptake by the belowground part; dotted line: $\mathrm{NH}_{4}{ }^{+}$uptake by the aboveground part; dashed lines: $\mathrm{NO}_{3}{ }^{-}+\mathrm{NO}_{2}{ }^{-}$uptake by aboveground part $\left({ }^{*} \mathrm{p}<0.05 ;{ }^{* *} \mathrm{p}<0.01 ;{ }^{* * *} \mathrm{p}<0.001\right)$

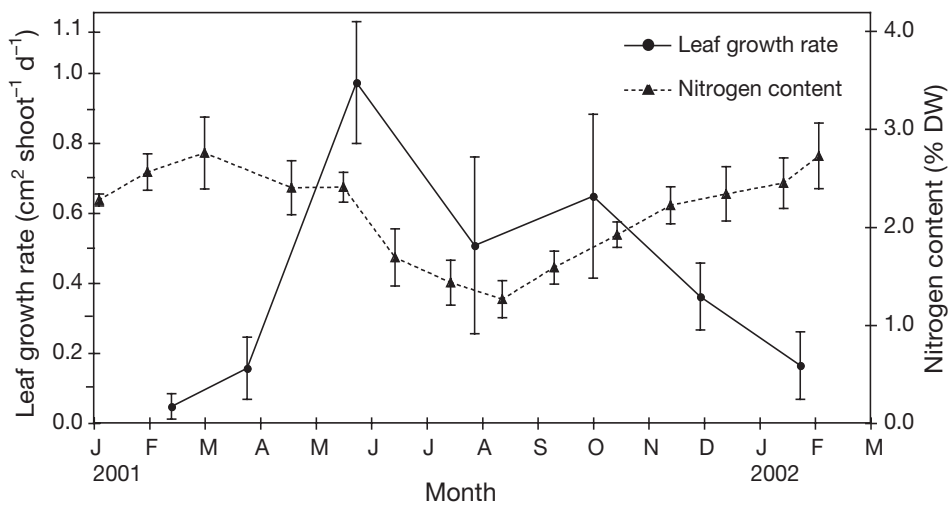

Fig. 11. Phyllospadix iwatensis. Seasonal changes in leaf growth rate and nitrogen content in the youngest leaf tissue. Vertical bars represent \pm 1 SD (elongation rate: $n=20$ to 30 , nitrogen content: $n=5$ )

uptake. However, there is no evidence for light conditions affecting nitrogen uptake in seagrass species. In $Z$. marina, diurnal variation has not been observed for nitrogen uptake (Iizumi \& Hattori 1982), and high nitrate reduced activity was maintained even during dark periods (Touchette \& Burkholder 2000). These reports suggest that short-term changes in light conditions (such as diurnal variation) do not affect seagrass nitrogen uptake, and that the light conditions in the experiments of this study (kept uniform at $100 \mu \mathrm{mol}$ photons $\mathrm{m}^{-2} \mathrm{~s}^{-1}$ in all experiments) would affect neither the measurement of nitrogen uptake kinetics nor the estimated nitrogen budget of $P$. iwatensis.

Both aboveground leaves and belowground roots of Phyllospadix iwatensis can function as nitrogen uptake organs; however, their contribution to nitrogen acqui- sition from each nitrogen source changed seasonally (Fig. 9). During spring and summer, $\mathrm{NO}_{3}{ }^{-}+$ $\mathrm{NO}_{2}{ }^{-}$concentration in the water column was very low $(<0.2 \mu \mathrm{M})$, but $\mathrm{NH}_{4}{ }^{+}$concentration in sediment porewater was high $(>100 \mu \mathrm{M})$. Thus, nitrogen acquisition from water column $\mathrm{NO}_{3}{ }^{-}+\mathrm{NO}_{2}{ }^{-}$ accounted for only a small percentage of total nitrogen acquisition. Porewater $\mathrm{NH}_{4}{ }^{+}$uptake by belowground parts was the main pathway from ambient nitrogen sources (57 to $89 \%$ ). In temperate coastal marine environments, including this study site, DIN concentration in the water column usually remains low after a spring bloom of phytoplankton. During this low nutrient season, seagrasses, including $P$. iwatensis, are at a greater advantage than other marine primary producers such as phytoplankton, epiphytes and seaweeds, because of the possibility of nitrogen acquisition from porewater $\mathrm{NH}_{4}{ }^{+}$. In contrast, from fall to winter, $\mathrm{NO}_{3}{ }^{-}+\mathrm{NO}_{2}{ }^{-}$concentration in the water column increased to $6 \mu \mathrm{M}$ after loss of water-column stratification; however, the range of $\mathrm{NH}_{4}{ }^{+}$ concentration in sediment porewater was lower than in spring and summer. $\mathrm{NO}_{3}{ }^{-}+\mathrm{NO}_{2}{ }^{-}$uptake from the water column, therefore, played a more important role in nitrogen acquisition ( 25 to $59 \%$ ), and the contribution of belowground nitrogen uptake decreased to about $30 \%$. Zimmerman et al. (1987) showed that the contributions of leaf and root nitrogen uptakes in Zostera marina varied as a function of ambient DIN concentration, and Lee \& Dunton (1999) demonstrated that contributions of leaf and root to the total nitrogen budget of Thalassia testudinum varied seasonally. This study reveals that the contributions of nitrogen acquisition from water column $\mathrm{NO}_{3}^{-}+\mathrm{NO}_{2}^{-}$and porewater $\mathrm{NH}_{4}^{+}$changed seasonally, mainly depending on the large seasonal fluctuation of the ambient nitrogen sources (Fig. 10). Otherwise, the contribution of nitrogen acquisition from water column $\mathrm{NH}_{4}{ }^{+}$did not change seasonally, as there was no seasonal fluctuation of $\mathrm{NH}_{4}{ }^{+}$concentration in the water column. Although the $\mathrm{NH}_{4}{ }^{+}$concentration in the water column was $<1 \mu \mathrm{M}$ in most seasons, water column $\mathrm{NH}_{4}{ }^{+}$was the important ambient nitrogen source since a $P$. iwatensis leaf has a higher uptake affinity for $\mathrm{NH}_{4}{ }^{+}$ than for $\mathrm{NO}_{3}{ }^{-}+\mathrm{NO}_{2}{ }^{-}$. As a nitrogen source, seagrasses prefer $\mathrm{NH}_{4}{ }^{+}$to $\mathrm{NO}_{3}{ }^{-}+\mathrm{NO}_{2}{ }^{-}$, which is energetically expensive to assimilate (Touchette \& Burkholder 2000). Moreover, aquatic plants have been suggested to take advantage of this higher uptake affinity to use the pulsed $\mathrm{NH}_{4}{ }^{+}$in the water column (Pedersen et al. 1997).

The nitrogen requirement in a shoot changed seasonally and was not always synchronized with the 
change of nitrogen acquisition (Fig. 8). From spring to summer, the nitrogen requirement increased dramatically depending on the increase of production, yet the nitrogen acquisition from the ambient source did not increase. The nitrogen acquisition in summer could, therefore, not satisfy the shoot nitrogen requirement. Particularly, nitrogen acquisition in a shoot in June 2001 supplied only $25 \%$ of the nitrogen requirement for growth of a shoot between May and June 2001, because the aboveground biomass during this season was suppressed by the ice scouring in the winter. In winter, the nitrogen requirement was lower than the nitrogen acquisition from ambient nitrogen. These results suggest that nitrogen is supplied not only from ambient nitrogen uptake but also from another nitrogen source during the high productive season, and that there is extra uptake of nitrogen in the low productive season. The shortage and excess of nitrogen would be offset by the internal nitrogen retention system of seagrass. Nutrient retention is a common phenomenon in vascular plants and the use of an internal nitrogen source would reduce the dependence on nitrogen uptake from ambient sources. Yet, Hemminga et al. (1999) concluded that seagrasses have comparatively poorly developed nutrient conservation strategies, and retranslocation represents only $15 \%$ of the nitrogen requirement. Otherwise, it has been suggested that nitrogen translocation accounts for $40 \%$ of the nitrogen requirement on an annual basis (e.g. Posidonia oceanica; Alcoverro et al. 2000). In Phyllospadix iwatensis, nitrogen translocation from an internal source through the retention system could play an important role in the growth of shoots as in P. oceanica, particularly in the high productive season (Fig. 12). Excess nitrogen during winter could be stocked in the storage organs such as rhizome and leaf sheath, which have been reported to function as carbon sources (Kuo et al. 1988). P. iwatensis has longer leaf longevity (166 d; Hamamoto \& Mukai 1999) than other seagrasses. An extended leaf life span is known to be an important mechanism in conserving nutrients and in reducing nutrient demands (Escudero et al. 1992). The long life span allows the seagrass to keep the nitrogen rich leaves made in winter on a shoot until summer and to function as a nitrogen storage organ.

Nitrogen content in plant tissue has been considered an index of plant nutrient status (Touchette \& Burkholder 2000). Short (1987) and Duarte (1990) reported that seagrass growth is nitrogen-limited when nitrogen content of leaves is lower than $1.8 \%$ DW. Nitrogen content of the youngest leaves of Phyllospadix iwatensis, which are generally the most nitrogen-rich, decreased to $1.3 \%$ DW (Fig. 11). Nitrogen supply by internal nitrogen translocation would relax the nitrogen limitation of production.

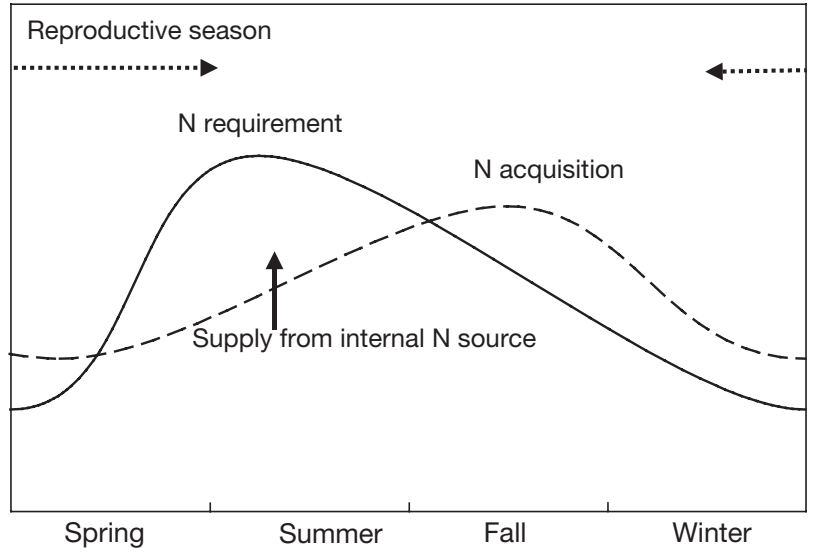

Fig. 12. Phyllospadix iwatensis. A model of seasonal change for nitrogen acquisition and requirement

Phyllospadix iwatensis develops the flowering spathe in early spring (Yabe et al. 1995, 1996). Phyllospadix torreyi has a higher nitrogen content in the spadix (3.3\% DW, cf. Williams 1995) than in the leaf (2.4\% DW; cf. Ramirez-Garcia et al. 2002). Flower formation represents a nitrogen sink, and the excess nitrogen in this season could contribute to the development of $P$. iwatensis flowers (Fig. 12).

In conclusion, Phyllospadix iwatensis can acquire nitrogen effectively from spatially different ambient sources (water column and porewater), which show different seasonal fluctuations. Seasonal differences between nitrogen demand and acquisition could be offset by the retention system. Differences in the development of belowground nutrient uptake and in the nutrient retention system in seagrass species could be the result of adaptation to coastal ecosystems, which have variable nutrient environments.

Acknowledgements. We would like to thank I. Koike, M. Nakaoka, Y. Sakanishi, T. Yabe and the members of the Laboratory of Marine Ecology, Hokkaido University for valuable comments. We also thank the anonymous reviewers for improving our manuscripts. We express our appreciation to M. Moroi, S. Hamano and H. Katsuragawa of the Akkeshi Marine Station, Hokkaido University, for logistical support.

\section{LITERATURE CITED}

Alcoverro T, Romero J, Duarte CM, Lopez NI (1997) Spatial and temporal variations in nutrient limitation of seagrass Posidonia oceanica growth in the NW Mediterranean. Mar Ecol Prog Ser 146:155-161

Alcoverro T, Manzanera M, Romero J (2000) Nutrient mass balance of the seagrass Posidonia oceanica: the importance of nutrient retranslocation. Mar Ecol Prog Ser 194: 13-21

Bulthuis AD, Axelrad DM, Mickelson MJ (1992) Growth of the seagrass Heterozostera tasmanica limited by nitrogen 
in Port Phillip Bay, Australia. Mar Ecol Prog Ser 89: 269-275

Dennison WC, Aller RC, Alberte RS (1987) Sediment ammonium availability and eelgrass (Zostera marina) growth. Mar Biol 94:469-477

Duarte CM (1990) Seagrass nutrient content. Mar Ecol Prog Ser 67:201-207

Escudero A, Del Arco JM, Sanz IC, Ayala J (1992) Effects of leaf longevity and retranslocation efficiency on the retention time of nutrients in the leaf biomass of different woody species. Oecologia 90:80-87

Hamamoto K, Mukai H (1999) Effects of larval settlement and postsettlement mortality on the distribution pattern and abundance of the spirorbid tube worm Neodexiospira brasilliensis (Grube) (Polychaeta) living on seagrass leaves. PSZN I: Mar Ecol 20:251-272

Hemminga MA, Koutstaal BP, Van Soelen J (1994) The nitrogen supply to intertidal eelgrass (Zostera marina). Mar Biol 118:223-227

Hemminga MA, Marba N, Stapel J (1999) Leaf nutrient resorption, leaf retention of nutrients in seagrass systems. Aquat Bot 65:141-158

Iizumi H, Hattori A (1982) Growth and organic production of eelgrass (Zostera marina) in temperate waters of the Pacific coast of Japan. III. The kinetics of the nitrogen uptake. Aquat Bot 12:245-256

Kenworthy WJ, Fonseca MS (1992) The use of fertilizer to enhance growth of transplanted Zostera marina L. and Halodule wrightii Aschers. J Exp Mar Biol Ecol 163: 141-161

Kuo J, Aioi K, Iizumi H (1988) Comparative leaf structure and its functional significance in Phyllospadix iwatensis Makino and Phyllospadix japonicus Makino (Zosteraceae). Aquat Bot 30:169-187

Lee KS, Dunton KH (1999) Inorganic nitrogen acquisition in seagrass Thalassia testudinum: development of a wholeplant nitrogen budget. Limnol Oceanogr 44:1204-1215

Nakamura H, Mukai H, Moroi M, Hamano S (2001) Meteorological and oceanographical measurements at Akkeshi Marine Biological Station. Activity report in 2000 from Akkeshi Marine Biological Station, p 19-37

Nakamura H, Mukai H, Moroi M, Hamano S, Katsuragawa H, Gomi H (2003) Meteorological and oceanographical measurements at Akkeshi Marine Station in 2001-2002. Activity report of Akkeshi Marine Station, p 36-65

Pedersen MF, Borum J (1992) Nitrogen dynamics of eelgrass Zostera marina during a late summer period of high growth and low nutrient availability. Mar Ecol Prog Ser 14:65-73

Pedersen MF, Borum J (1993) An annual nitrogen budget for seagrass Zostera marina population. Mar Ecol Prog Ser 101:169-177

Pedersen MF, Paling EI, Walker DI (1997) Nitrogen uptake and allocation in the seagrass Amphibolis antarctica. Aquat Bot 56:105-117

Ramirez-Garcia P, Terrados J, Ramos F, Lot A, Ocaña D, Duarte CM (2002) Distribution and nutrient limitaion of

Editorial responsibility: Otto Kinne (Editor-in-Chief), Oldendorf/Luhe, Germany surfgrass, Phyllospadix scouleri and Phyllospadix torreyi, along the Pacific coast of Baja California (México). Aquat Bot 74:121-131

Short FT (1987) Effects of sediment nutrients on seagrasses: literature review and mesocosm experiments. Aquat Bot 27:41-67

Short FT, Duarte CM (2001) Methods for the measurement of seagrass growth and production. In: Short FT, Coles RG (eds) Global seagrass research methods. Elsevier Science BV, Amsterdam, p 155-182

Short FT, McRoy CP (1984) Nitrogen uptake by leaves and roots of the seagrass Zostera marina L. Bot Mar 27: $547-555$

Stapel J, Aarts TL, van Duynhoven BHM, de Groot JD, van den Hoogen PHW, Hemminga MA (1996) Nutrient uptake by leaves and roots of seagrass Thalassia hemprichii in Spermonde Archipelago, Indonesia. Mar Ecol Prog Ser 134:195-206

Stapel J, Hemminga MA (1997) Nutrient resorption from seagrass leaves. Mar Biol 128:197-206

Strickland JDH, Parsons TR (1968) A practical handbook of seawater analysis. Bull Fish Res Bd Can 167

Terrados J, Williams SL (1997) Leaf versus root nitrogen uptake by the surfgrass Phyllospadix torreyi. Mar Ecol Prog Ser 149:267-277

Thursby GB, Harlin MM (1982) Leaf-root interaction in the uptake of ammonia by Zostera marina. Mar Biol 72: 109-112

Thursby GB, Harlin MM (1984) Interaction of leaves and roots of Ruppia maritima in the uptake of phosphate, ammonia and nitrate. Mar Biol 83:61-67

Topinka JA (1978) Nitrogen uptake by Fucus spiralis (Phaeophyta). J Phycol 14:241-247

Touchette BW, Burkholder JM (2000) Review of nitrogen and phosphorus metabolism in seagrasses. J Exp Mar Biol Ecol 250:133-167

Udy JW, Dennison WC (1997) Growth and physiological responses of three seagrass species to evaluated sediment nutrients in Moreton Bay, Australia. J Exp Mar Biol Ecol 217:253-277

Williams SL (1995) Surfgrass (Phyllospadix torreyi) reproduction: reproductive phenology, resource allocation, and male rarity. Ecology 76:1953-1970

Yabe T, Ikusima I, Tsuchiya T (1995) Production and population ecology of Phyllospadix iwatensis Makino. I. Leaf growth and biomass in an intertidal zone. Ecol Res 10: 291-299

Yabe T, Ikusima I, Tsuchiya T (1996) Production and population ecology of Phyllospadix iwatensis Makino. II. Comparative studies on leaf characteristics, foliage structure and biomass change in an intertidal and subtidal zone. Ecol Res 11:291-297

Zimmerman RC, Smith RD, Alberte RS (1987) Is growth of eelgrass nitrogen limited? A numerical simulation of the effects of light and nitrogen on the growth dynamics of Zostera marina. Mar Ecol Prog Ser 41:167-276

Submitted: August 6, 2003; Accepted: December 2, 2004 Proofs received from author(s): April 28, 2005 